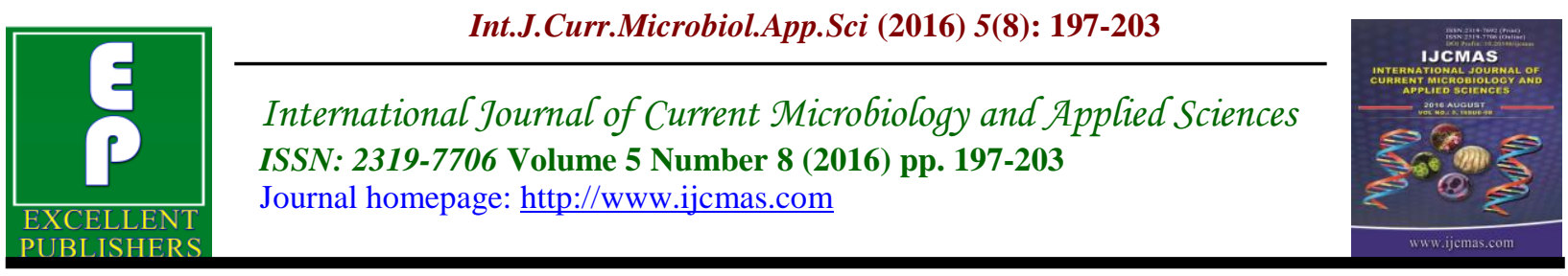

Original Research Article

http://dx.doi.org/10.20546/ijcmas.2016.508.021

\title{
A Study on Bacterial Pathogens causing Secondary Infections in Patients Suffering from Tuberculosis and their Pattern of Antibiotic Sensitivity
}

\author{
Amaryllis Langbang ${ }^{1}$, Nabajit Deka ${ }^{2}$, Hafizur Rahman ${ }^{1}$ and Devjyoti Kalita ${ }^{3}$ \\ ${ }^{1}$ Regional Drug Testing Laboratory, Guwahati, 781037, Assam, India \\ ${ }^{2}$ Department of Microbiology, Gauhati Medical College Hospital, Guwahati, 781032, \\ Assam, India \\ ${ }^{3}$ Department of Pharmaceutical Sciences, Dibrugarh University, Dibrugarh, 786004, \\ Assam, India \\ *Corresponding author
}

\begin{tabular}{|c|c|}
\hline & A B S T R A C T \\
\hline & \multirow{10}{*}{$\begin{array}{l}\text { Tuberculosis (TB) is a potentially serious infectious disease infections began } \\
\text { increasing in 1985, partly because of the emergence of HIV. India is the highest TB } \\
\text { burden country with World Health Organisation (WHO) statistics for } 2011 \text { giving } \\
\text { an estimated incidence figure of } 2.2 \text { million cases of TB for India out of a global } \\
\text { incidence of } 8.0 \text { million cases. Secondary bacterial infection is one of the most } \\
\text { important complications in patients with pulmonary tuberculosis. So it become } \\
\text { important to study about secondary infection associated with tuberculosis. In our } \\
\text { study we tried to isolate Bacterial pathogens causing secondary Bacterial infection } \\
\text { in patients suffering from tuberculosis. In duration of } 3 \text { months, w.e.f February to } \\
\text { April } 2015 \text { the total number of } 50 \text { positive sputum samples examined for secondary } \\
\text { infection where Staphylococcus aureus is the most common pathogen isolated } \\
\text { which constitute around } 32 \% \text { while Klebsiella pneumonia constitute the least with } \\
\text { just } \$ \% \text {.After isolation we have studied about drug sensitivity of these pathogens } \\
\text { by disc diffusion method and found all } 8 \text { isolates of Moraxella catarahallis are } \\
\text { resistant against ciprofloxacin. } 3 \text { isolate among the } 16 \text { isolates of Staphylococcus } \\
\text { aureusis resistant against erythromycin and oxacillin..Most of isolated gram } \\
\text { negative bacilli was resistant against Amikacine, Ampicillin,Ciprofloxacin.All the } \\
\text { isolates of Pseudomonas aeruginosa was resistant against Amikacine, } \\
\text { Ciprofloxacin. }\end{array}$} \\
\hline Keywords & \\
\hline & \\
\hline & \\
\hline & \\
\hline & \\
\hline & \\
\hline Article Info & \\
\hline $\begin{array}{l}\text { Accepted: } \\
\text { 12 July } 2016 \\
\text { Available Online: } \\
10 \text { August } 2016\end{array}$ & \\
\hline & \\
\hline
\end{tabular}

\section{Introduction}

Tuberculosis (TB) is a potentially serious infectious disease that mainly affects our lungs. Once rare in developed countries, tuberculosis infections began increasing in 1985, partly because of the emergence of
HIV. India has approximately two to three million people infected with Tuberculosis. India is the highest TB burden country with World Health Organisation (WHO) statistics for 2011 giving an estimated incidence 
figure of 2.2 million cases of TB for India out of a global incidence of 8.0 million cases (Southwick et al., 2007). Tuberculosis is the biggest health issue that lies around India, but what makes is worse is the newly and recently discovered global phenomenon of TDR-TB-Totally Drug-Resistant TB started off with MDR-TB, and moved on to XDRTB. Along with drug resistance, Secondary bacterial infection also become the most important complications in patients with pulmonary tuberculosis. The major reason is the inhibition of human defence forces during the course of active tuberculosis. It has been confirmed by studies who worked on immune response of lung cell during experimental tuberculosis in mice. In another study, $\mathrm{T}$ lymphocyte deficiency in patients with infiltrative pulmonary tuberculosis was observed. Another reason for lowering of immune system of tuberculosis patients might be the hormonal changes such as inhibited pituitary function, higher adrenal activity, elevated cortisol level, altered thyroid function and increased pancrease functional activity during the initial period of tuberculosis. It has also been observed that the alveolar lining material of patient with active Pulmonary tuberculosis has less bactericidal activity against bacterial infection.

\section{Materials and Methods}

\section{Place and Duration of study}

The study was conducted at the Department of Microbiology, Assam Down Town University from February 2015 to April 2015.

\section{Selection of isolates}

Patients admitted in TB Hospital, Guwahati and TB Chest Hospital, Shillong for their tuberculosis treatment are the subject of the study. On the basis of the clinical finding and physician's recommendation patients having some complication like nonsubsiding fever, cough, Stomach pain, muscle pain, Chest pain in spite of taking antituberculosis drugs were selected as subject of the study.

\section{Processing of samples}

Isolates were identified by standard microbiological procedures (Gram staining, colonial morphology, slide and tube coagulase test, motility, biochemical tests). Reference strain of gram positive cocci Staphylococcus aureus ATCC 35556, gram negative bacilli Pseudomonas aeruginosa ATCC were used as control. After proper identification we have studied about the drug pattern of the identified microorganisms by disc diffusion method based on Clinical Laboratory Standards Institute (CLSI, formerly National Committee for Clinical Laboratory Standards (NCCLS), 2004. Mueller-Hinton agar (hi-media) was inoculated with a suspension prepared from identified micro-organisms. The antifungal disc (hi-media) was then placed on the medium and the plate was incubated at $37^{\circ} \mathrm{C}$. The zone size was measured after 24 hours and interpreted as per approved CLSI guideline.

\section{Result and Discussion}

Total 50 numbers of sputum sample from T.B. patient with secondary infection were collected. The organisms isolated from the sputum sample and identified where Staphylococcus aureus (32\%) is major pathogen followed by Pseudomonas aeruginosa (16\%), Moraxella catarahallis (14\%), Staphylococcus epidermidis (12\%), Escherichia coli and Streptococcus pyogenes (8\%), Hemophilus influenza (6\%). Here we found Klebsiella pneumonia as 
least found micro-organsim which is $4 \%$. When we studied their drug pattern, found that all 8 isolates of Moraxella catarahallis are resistant against ciprofloxacin. 3 isolate among the 16 isolates of Staphylococcus aureus is resistant against erythromycin and oxacillin. Most of isolated gram negative bacilli was resistant against Amikacine, Ampicillin, Ciprofloxacin. All the isolates of Pseudomonas aeruginosa was resistant against Amikacine, Ciprofloxacin, ceflazidine.

M. Nagatak et al., (2014), had studied that the causative microorganism of the secondary infections in patients with tuberculosis sequele were essentially similar in those with other lower respiratory tract infection.i.e. Chronic bronchitis, bronchiectasis, diffuse panbonchiolitis, chronic pulmonary emphysema, etc. According to their clinical observation they clearly demonstrated that there were differences between the causative microorganism in patients hospitalalized during 1988 to1989 and those in patients without admission. Gram-negative bacilli, including P.aeruginosa, GNF-GNB and GFGNB, and Staphylococcus aureus were predominant in hospitalized patients. On the contrary, Streptococcus pneumonia, H.influenza, and Branhamella catarrhalis were major pathogenic bacteria in patients without hospitalization (Shishido et al., 2014). Here in our study also we have found Staphylococcus aureus as most predominant micro-organism followed by P.aeruginosa.

Zakaria et al., 2013 in a studied on the current Status of secondary Infection of Pulmonary T.B. among 450 TB suspected patients during September to December 2012 periods in Bangladesh. Among those, 100 samples were cultured for isolating secondary bacterial infection of newly detected pulmonary TB (PTB) patients whose are already treated by TB drugs. From these cultured samples, 22 were isolated as Klebsiella spp and 10 were isolated as Staphylococus (Joynal et al., 2013). Here in our study we have found Staphylococcus as mostly found isolates nearly 44\%including coagulase negative staphylococcus but Klebsiella is found least numbers nearly $4 \%$

Southwick et al., (2007) had studied that Isolation of secondary bacterial infection from the pulmonary tuberculosis patients from the new cases and failure of tuberculosis treatment. The antimicrobial susceptibility to the isolated secondary bacterial infection in pulmonary tuberculosis in the new and failed treated cases.

Table.1 List of Isolated Micro-organisms from Sputum Samples

\begin{tabular}{|l|c|}
\hline Name of Isolated organism & No of Isolate from sputum sample \\
\hline Staphylococcus aureus & $32 \%$ \\
\hline Pseudomonas aeruginosa & $16 \%$ \\
\hline Moraxella catarahallis & $14 \%$ \\
\hline Staphylococcus epidermidis & $12 \%$ \\
\hline Escherichia coli & $8 \%$ \\
\hline Streptococcus pyogenes & $8 \%$ \\
\hline Hemophilus influenza & $6 \%$ \\
\hline Klebsiella pneumoniae & $4 \%$ \\
\hline
\end{tabular}


Table.2 Antibiotic Susceptibility profile of isolates

\begin{tabular}{|c|c|c|c|}
\hline Isolated Micro-organism & Antibiotic used & Susceptible & Resistance \\
\hline \multirow[t]{11}{*}{ Staphylococcus aureus } & Cefoxitine & $\mathrm{S}$ & \\
\hline & Cefuroxime & $S$ & \\
\hline & Cephaloxin & $\mathrm{S}$ & \\
\hline & Co-trimoxazole & $\mathrm{S}$ & \\
\hline & Erythromycin & $\mathrm{S}$ & $\mathrm{R}(3$ isolates $)$ \\
\hline & Oxacillin & $\mathrm{S}$ & $\mathrm{R}(3$ isolates $)$ \\
\hline & Penicillin & $S$ & \\
\hline & Chloramphenicol & S & \\
\hline & Linezolid & $\mathrm{S}$ & \\
\hline & Ofloxacin & $S$ & \\
\hline & Vancomycin & $\mathrm{S}$ & \\
\hline \multirow[t]{9}{*}{ Pseudomonas aeruginosa } & Amikacin & & $\mathrm{R}$ \\
\hline & Ceflazidine & & $\mathrm{R}$ \\
\hline & Tazobactum & $S$ & \\
\hline & Ciprofloxacin & & $\mathrm{R}$ \\
\hline & Gentamycin & $S$ & \\
\hline & Ofloxacin & $\mathrm{S}$ & \\
\hline & Cefeprime & $\mathrm{S}$ & \\
\hline & Imipenem & $\mathrm{S}$ & \\
\hline & Tobramycin & $\mathrm{S}$ & \\
\hline \multirow{12}{*}{$\begin{array}{l}\text { Moraxella catarahallis } \\
\text { Escherichia coli } \\
\text { Klebsiella pneumonia }\end{array}$} & Amikacin & & $\mathrm{R}$ \\
\hline & Ampicillin & & $\mathrm{R}$ \\
\hline & Ceftriaxone & $\mathrm{S}$ & \\
\hline & Cefuroxime & $\mathrm{S}$ & \\
\hline & Cephalothin & $\mathrm{S}$ & \\
\hline & Ciprofloxacin & & $\mathrm{R}$ \\
\hline & GentamycineSulbactum & $\mathrm{S}$ & \\
\hline & Cefepime & $\mathrm{S}$ & \\
\hline & Ceftazidine & $\mathrm{S}$ & \\
\hline & Clavulonic acid & $\mathrm{S}$ & \\
\hline & Imipenem & $\mathrm{S}$ & \\
\hline & Ofloxacin & $\mathrm{S}$ & \\
\hline \multirow[t]{9}{*}{ Hemophilus influenza } & Ampicillin & $\mathrm{S}$ & \\
\hline & Cefuroxime & $S$ & \\
\hline & Chrolamphenicol & $\mathrm{S}$ & \\
\hline & C0-trimoxazole & $\mathrm{S}$ & \\
\hline & Tetracycline & $\mathrm{S}$ & \\
\hline & Ampicillin & $\mathrm{S}$ & \\
\hline & Ciprofloxacin & $\mathrm{S}$ & \\
\hline & Erythromycin & $\mathrm{S}$ & \\
\hline & Penicillin & $\mathrm{S}$ & \\
\hline
\end{tabular}


Int.J.Curr.Microbiol.App.Sci (2016) 5(8): 197-203

\begin{tabular}{|l|l|l|l|}
\hline & Vancomycin & S & \\
\hline \multirow{5}{*}{ Streptococcus pyogenes } & Cephalothin & S & \\
\cline { 2 - 5 } & Clindomycin & S & \\
\cline { 2 - 4 } & Co-trimoxazole & S & \\
\cline { 2 - 5 } & Erythromycin & S & \\
\cline { 2 - 4 } & Penicillin & S & \\
\hline
\end{tabular}

Fig.1 Sugar fermentation test for Species identification

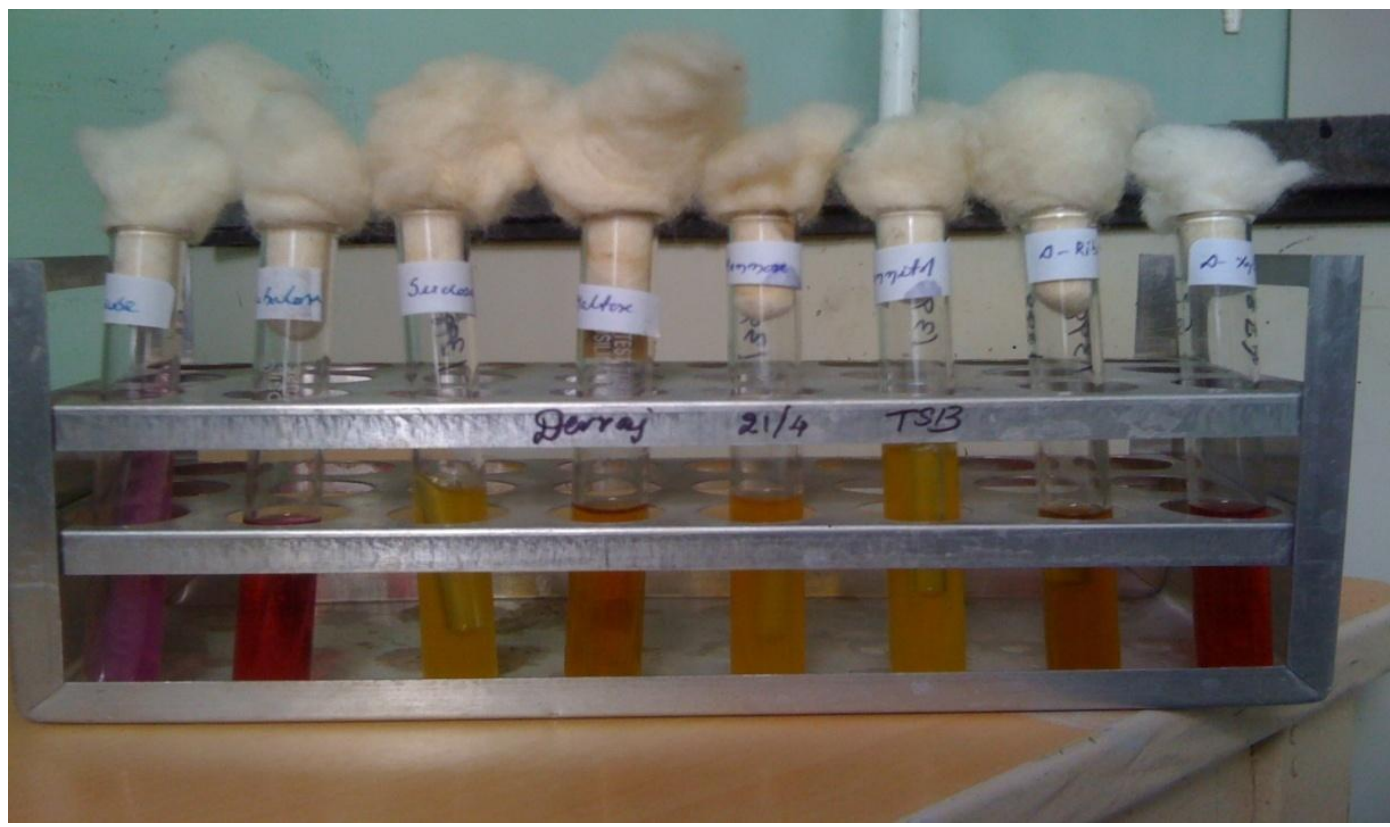

Fig.2 Antibiotic Susceptibility Testing by disc Diffusion Method

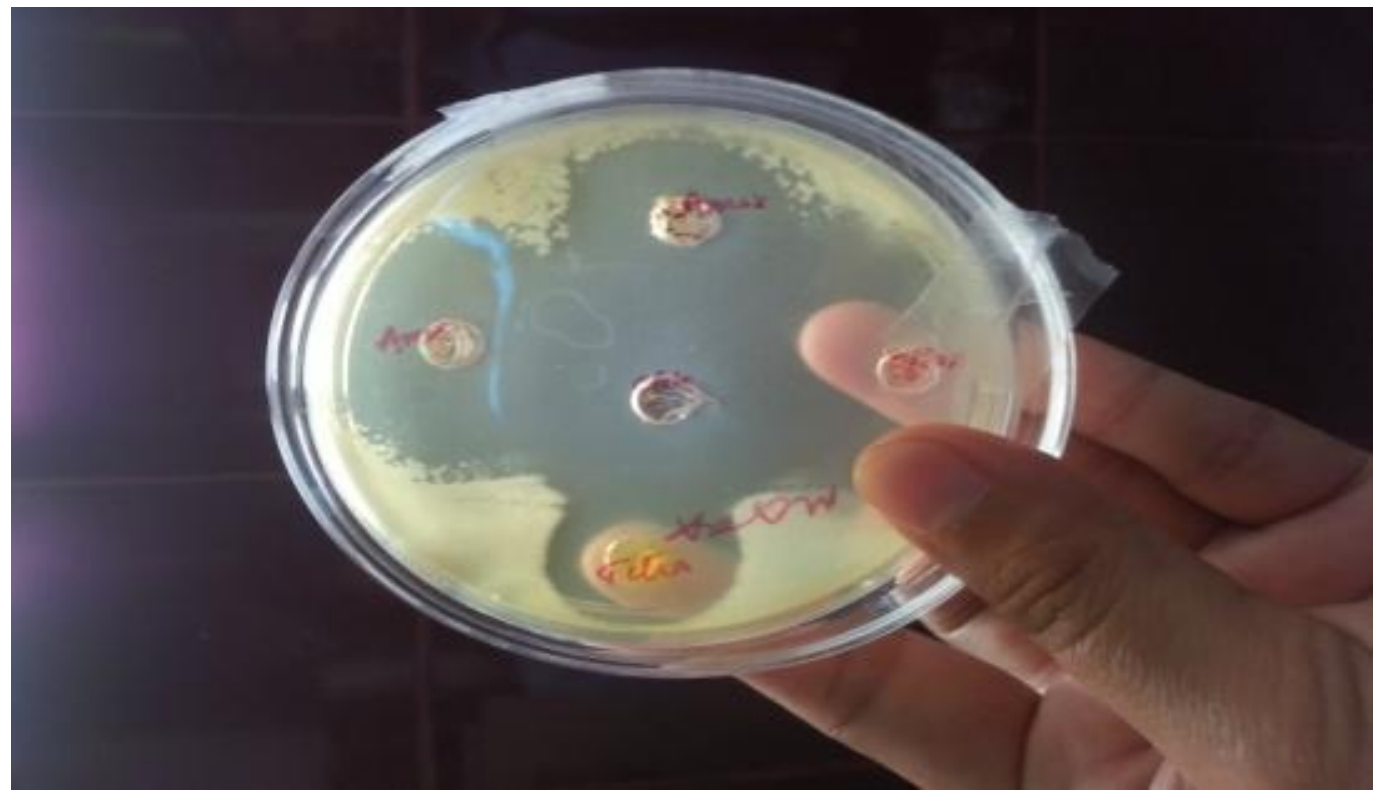


Fig.3

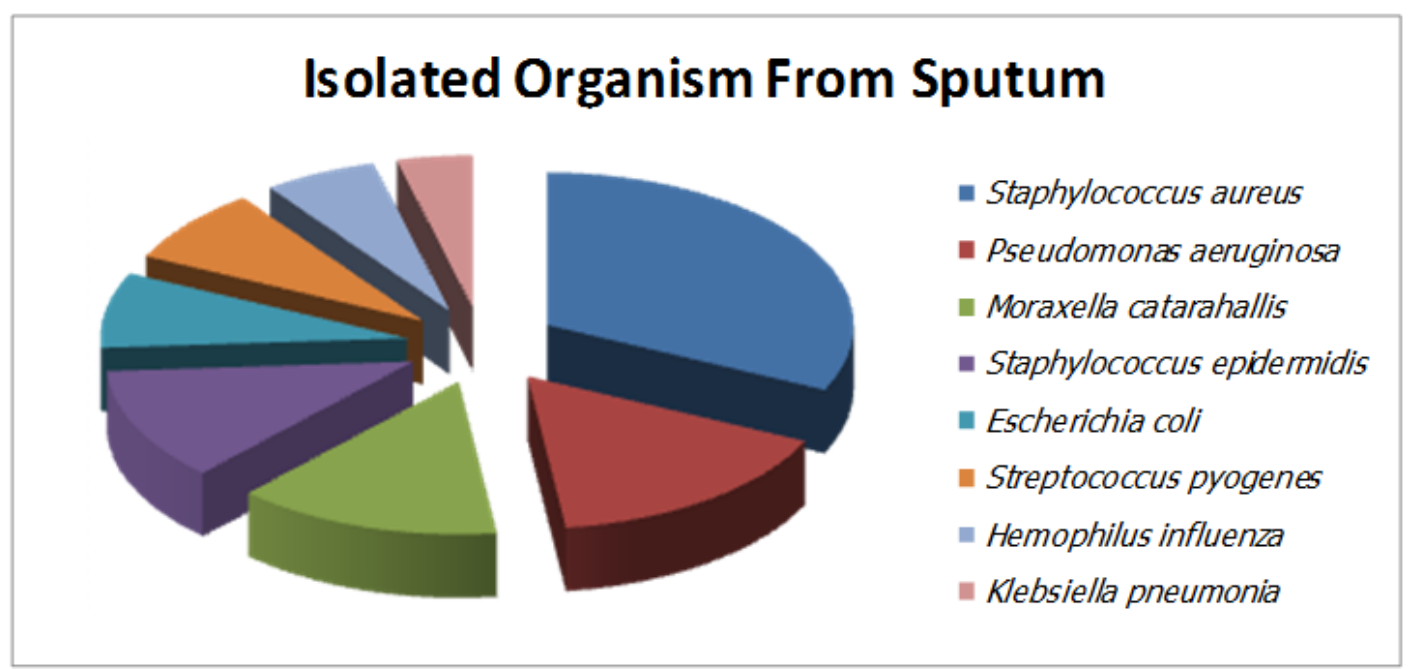

From the 50 collected sputum specimens, the results show the percentage of positive secondary bacterial infection is $72 \%$ (n. 36), and negative is $28 \%$ (n.14), also the study showed that 27 from the 36 cases had a positive secondary bacterial infection were from new cases $75 \%$, while only 9 of 36 cases had a positive secondary bacterial infection were from failure of tuberculosis treatment $25 \%$.The secondary bacterial infection in pulmonary tuberculosis were found in 21 male patients $(58.3 \%)$ and 15 in female patients $(40.7 \%)$.

In this study there was an isolation four types of secondary bacterial infection in those 36 patients such as: 20 patients with Streptococcus pneumoniae (55.6\%), 8 with Streptococcus pyogens (22.2\%), 4 with Staphylococcus auras (11.1\%) and 4 with Klebsiela pneumoniae (11.1\%) . In this most of organisms were resistance against respected antibiotics (Southwick et al., 2007). Here in our study except Streptococcus pneumoniae, we have found all other micro-organisms and their drug pattern shows that they were resistant against some important drugs like Amikacine, Ampicillin, Ciprofloxacin, Erythromycin, Oxacillin.
Jasmer et al., (2002) in a study titled "Clinical practice. Latent tuberculosis infection" found that Pseudomonas aeruginosa, was the major pathogenic bacteria responsible for the chronic respiratory failure and/or fatal outcome in the post-tuberculosis patients. Patients with complication, including aspergilosis, atypical mycobacteriosis, bronchial asthma, and so forth, showed no specific causative microorganism for the secondary infection except frequent isolation of Haemophilus influenza (Jasmer et al., 2002). In our study we have found staphylococcus aureus (32\%) as a major pathogen followed by Pseudomonas aeruginosa (16\%).

\section{References}

Bergeys manual of determinative Bacteriology $\left(9^{\text {th }}\right.$ Edition $)$

Connie, R. Mohan, George Manuselis : Textbook of Diagnostic Microbiology.

Shaddock, E., N. Bosman, T. Nana, C. Sriruttan, C. Feldman. 2014. South Afr. J. Infect. Dis., 29(1): 23-26.

Jasmer, R.M., Nahid, P., Hopewell, P.C. 2002. "Clinical practice. Latent 
tuberculosis infection". N. Engl. J. Med., 347(23): 1860-6.

Kenneth, J., Ryan, C., George Ryan. Sherris Medical Microbiology(an introduction to infectious disease).

Cristina, M., Peter, M., Small, et al. 2006. Variable host-pathogen in Mycobacterium tuberculosis". Nature Int. Interdisciplinary J. sci. .vol.103:,2869-2873

Joynal Abedin Khan, Md., Zakaria Ahmed. Department of Microbiology, Primeasia University, Retrived on May 2,2013,Study on the Current Status of Secondary Infection of Pulmonary tuberculosis, www.academia.edu, 3223351: 11-16.

Patrick, R., Murry, Ellen Jo Baron, James, H., Jorgensens, Marie Lewis Landy, Michael, A., P. Pallem. Manual of clinical microbiology.

Patric, R., Murry, Ken, S., Rosenthal, Michael A., Pfakeer. Medical Microbiology.

RNTCP Guidelines on PMDT in India. Central TB Division, Directorate General of Health Services, Ministry of Health \& Family Welfare, Nirman Bhavan, New Delhi-110011.
Rowland, K. 2012. Totally drug-resistant TB emerged in India: Nature News \& Comment. Nature Publishing Group: Science journals,job and information. Retrieved April 3, 2013

Shishido, H., Nagai, H., Kurashima, A., Yoneda, M., Nagatake, T., Matsumoto, K. et al. 2014. International Journal of Tuberculosis and Lung Disease," Tuberculosis sequelae: secondary bacterial infections, 873-880.

Southwick, Frederick. 2007. "Chapter 4: pulmonary infection". Infectious Diseases: A Clinical short course, $2^{\text {nd }}$ ed. McGraw-Hill Medical Publishing Division.P.104ISBN 0071477225.

Sunita Bansod and Mahendra Rai. 2008. Emerging Mycotic Infection in Patient infected with T.B., World J. medical sci.,3(2): 74-80.

Shailaja, V.V., L.A. Pai, D.R. Mathur, V. Lakshmi. et al. 2004. Prevalence of bacterial and fungal agents causing lower respiratory tract infection in patients with HIV infection, Indian J. Med. Microbiol., 22: 28-33.

\section{How to cite this article:}

Amaryllis Langbang, Nabajit Deka, Hafizur Rahman and Devjyoti Kalita. 2016. A Study on Bacterial Pathogens causing Secondary Infections in Patients Suffering from Tuberculosis and their Pattern of Antibiotic Sensitivity. Int.J.Curr.Microbiol.App.Sci. 5(8): 197-203. doi: http://dx.doi.org/10.20546/ijcmas.2016.508.021 